\title{
Dictynna
}

Dictynna

Revue de poétique latine

16 | 2019

Varia

\section{Nescioquid maius: Gender, Genre, and the Repetitions of Ovid's Medea}

\section{Barbara W. Boyd}

\section{(2) OpenEdition \\ 1 Journals}

\section{Electronic version}

URL: http://journals.openedition.org/dictynna/1962

DOI: 10.4000/dictynna.1962

ISSN: 1765-3142

\section{Electronic reference}

Barbara W. Boyd, « Nescioquid maius: Gender, Genre, and the Repetitions of Ovid's Medea », Dictynna [Online], 16 | 2019, Online since 18 December 2019, connection on 10 September 2020. URL : http:// journals.openedition.org/dictynna/1962; DOI : https://doi.org/10.4000/dictynna.1962

This text was automatically generated on 10 September 2020 .

\section{(c) (i) (9)}

Les contenus des la revue Dictynna sont mis à disposition selon les termes de la Licence Creative Commons Attribution - Pas d'Utilisation Commerciale - Pas de Modification 4.0 International. 


\title{
Nescioquid maius: Gender, Genre, and the Repetitions of Ovid's Medea
}

\author{
Barbara W. Boyd
}

\section{The Birth of a New Genre?}

1 In the first stasimon of Euripides' Medea, the chorus of Corinthian women expresses sympathy for the grim fate that Medea faces, sentenced to an isolated exile (Med. 431-45). The lament of the chorus opens with generalizing reflections on the common fate of women, destined only for slander if mentioned at all by the poets; though no poets are identified by name, it is easy to imagine that Hesiod and Semonides would be at the head of a very long list. ${ }^{1}$ In terms that are both wistfully evocative of a utopia in which men rather than women would be objects of distrust, and palpably ironic following the preceding speech of Medea detailing her own devious stratagems (364-409), the chorus imagines a profound reversal of the prevailing social and cultural order that oppresses women (410-20). In this alternative universe, restorative justice will take poetic form (417-30):

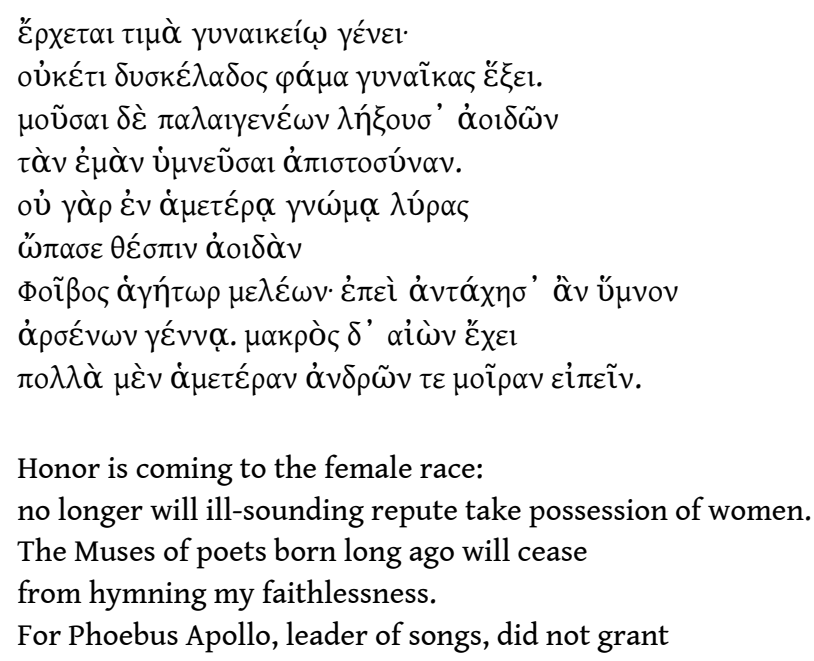


god-inspired song accompanied by the lyre to our knowledge;

since [otherwise] I would have sung a song in opposition

to the race of men. For the fullness of time has much to say

about both our destiny and that of men.

In an influential discussion of these verses, Froma Zeitlin notes that this radical vision entails nothing less than the creation of "a new genre of poetry that celebrates the exploits of women rather than those of men"; ${ }^{2}$ the impossibility of such a creation is implicit in Zeitlin's reading. More recently, however, Marianne Hopman has argued that Euripides' play itself enacts this new genre through its metapoetic reflection on what the genre of tragedy can and cannot do. ${ }^{3}$ Hopman focuses attention on the interaction of gender and genre, suggesting that, while the epic tradition in which the saga of the Argo arises is fundamentally androcentric, Euripides claims a new identity for tragedy to distinguish it from epic; in this new identity, tragedy reveals itself to be "congenial to women," and in the process declares its freedom from the strictures of the epic code. In Hopman's reading, epic kleos remains inaccessible to women by virtue of their gender's association with revenge; on the tragic stage, however, Medea (and others like her) can at least temporarily appropriate it. ${ }^{5}$

The exploration of and experimentation with the limits of genre, along with a distinct interest in exploring alternative perspectives on kleos offered by female protagonists, are well-known features of Euripides' work; it is not surprising, therefore, that Ovid looks first and foremost (though not exclusively, as we shall see) to Euripides when he takes up the story of Medea-and not once, but repeatedly. Only two fragments of his own Medea tragedy have survived, ${ }^{6}$ and they are too slight to offer any new insight into how Ovid's version might have drawn on or differed from the Euripidean one; in fact, Dan Curley has argued that perhaps its most interesting feature was, and remains, its singularity-that is, that in spite of the turn to tragedy heralded in the Amores, especially poems 3.1 and 3.15 , all the available evidence indicates that Ovid wrote only one such play, and then returned to elegy.7 This singularity is indeed noteworthy, especially since Ovid's interest in tragedy is quite obvious elsewhere in the corpus of his work; but unlike Curley, I want to focus instead on how Ovid uses the character and story of Medea repeatedly, and how the phenomenon of repetition itself is not only selfreferential but also metatextual, allowing Ovid both to explore and to comment upon the generic parameters of his work and upon the possibility of creating something new. 8

First, however, I return to Euripides, whose emphasis on Medea's gender is a crucial aspect of his (and her) challenge to the boundaries of genre; thereafter I move on to consider how Ovid appropriates and responds to this emphasis, in the process testing, and at least temporarily exceeding, the very boundaries he foregrounds.

\section{Surviving Motherhood}

4 In her first speech on the Euripidean stage, Medea juxtaposes the fate of women in Athenian culture to that of men (Med. 230-58). Men, she says, are the recipients of honor and glory in return for their display of military valor, in recompense for which they gain both public recognition and material goods; and they receive all this in addition to the economic advantage that they derive from the possession of a wife and her dowry. Women's lives are anonymous by comparison, even ignominious-especially the lives of foreign women like her-and the only alternative to obscurity available to 
them is the risk of social disgrace. Even the physical phenomenon of childbirth, avers Medea-not only labor, but the constant threat of death-is so exceptional an experience, so terrifying, that she would choose to have stood on the field of battle three times rather than to have given birth a single time: "I would prefer to stand by

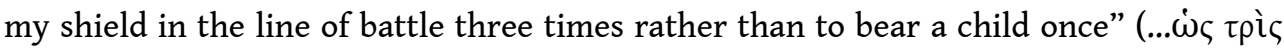

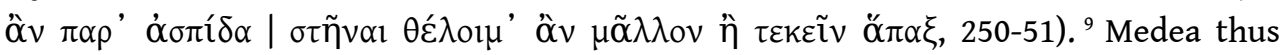
compares her situation as a tragic character with that of all the heroes-naturally, all male-of Greek epic, and asserts that in becoming a mother she has surpassed all the accomplishments of men on the battlefield. In addressing the difference between male warriors and herself, Medea challenges the hierarchy upon which this difference is based, simultaneously suggesting that the truly heroic undertaking, the truly exceptional achievement, is not in fact that performed by men but is hers. ${ }^{10}$

5 In the world of epic, the absolute finality of death on the battlefield is countered by epic's insistence on affirming the survival of a civilization at a moment of crisis: through the epic poet's use of similes depicting an alternative universe of peace and harmony with nature, the destruction that is narrated within the poem is countered by the very survival of the poem itself and its poet-a counterpoint that thus has a simultaneously ideological and literary dimension. ${ }^{11}$ When Euripides' tragic Medea compares the life of women to that of men, she offers a very different way of approaching the challenge she faces both as a character in Euripides' play and as a cocreator of its story: instead of harmony and ideological clarity, she knows only the risks of and to her own womanhood, not sustained by civilization but barely surviving on its fringes. Thus, when she distinguishes between herself and the other women of Corinth (Med. 253-58), she draws attention to the isolation that puts her outside the harmonious confines of life as it is delimited by the gendered world of the citizens, men and women, of Athens. As opposed to the world of Homeric epic, where human experience is organized around stabilizing binaries (peace/war; male/female; Greek/Trojan), the world that Medea inhabits is complex and unstable; in it there are no clear points of reference for her experience. The identity that Medea defines for herself-the identity that will make her immortal-is sui generis, making her an outlier even on the tragic stage, a place that has room to accommodate vulnerable heroines like Phaedra, Alcestis, and Electra. Medea understands that the continuity promised by epic ideology can only be destructive to her, and that the solution, therefore, lies not in maintaining continuity, but in destroying it.

6 In his study of the literary heirs to Virgilian epic, Philip Hardie has demonstrated how the relationship between epic poets and their models is often configured through selfreferential allusions involving a relationship of dependence, paternity, or succession. ${ }^{12}$ In other words, characters who can be identified as descendants of the central figures of earlier literary tradition, e.g., descendants of the Trojan or Theban heroes, frequently offer a model for the construction by younger poets of a relationship with their predecessors, represented as parents or ancestors. Medea constitutes a unique challenge to this model of intertextuality: she has broken all links to her past life in Colchis with the betrayal of her father and the murder of her brother, and she repeatedly destroys the familial bonds of others, as seen with the families of Pelias and Creon. Most important, she does this as a woman. Euripides offers a radically new revision of the intertextual trope of paternity when, with his Medea, he portrays a mother who kills her children in order to ensure her own survival in subsequent 
literary tradition; in other words, he replaces epic paternity with the embodiment of a self-consuming maternity that enables a self-perpetuating succession. The male heroes of Greek epic wage war and confront superhuman challenges that assure their survival in the memory of posterity; waging her own private war with Jason, Medea instead ensures her own survival by annihilating the memory of her descendants and negating any possibility of Jason's succession. ${ }^{13}$

7 Underscoring the physical ability necessary to fight on the one hand and to give birth on the other, Euripides' Medea asserts on her own behalf the heroic status that society normally makes available only to men-like Jason; at the same time, she problematizes the dramatic action to follow. In killing her children, Medea also negates her own status as mother and any distinction attached to that status. Yet her power and control over the situation only increase with the death of her children; Euripides makes this point explicit both textually and visually when he uses the deus ex machina device to bring her onstage at the close of the play, with the dead children at her feet in the winged chariot that hovers over Jason (1317-22). ${ }^{14}$ And as Hopman has argued, Medea's power and control as manifested at the end of the play can be read in a metapoetic light, emphasizing as they do her "appropriation of the tragic genre" 15 : as she wreaks her revenge, she both creates her own tragedy and comments on her ability to transcend it.

8 This closing scene guarantees Medea's survival into the future; she has already secured a promise from Aegeus of safe harbor in Athens, and as Euripides' Athenian audience would have known well, her career in myth is far from over. Simultaneously, however, Medea's infanticide constitutes an inversion of narrative time, along the lines of what Alessandro Barchiesi calls the "future reflexive," ${ }^{16}$ since it restores Medea to her childless status and so reverses the reproductive imperative. ${ }^{17}$ Maternity is a fundamental concern of Greek myth, as it is a cornerstone not only of the family but of civilized society writ large; childbearing and child care define the appropriate function and place of mortal women in the Greek patriarchy. ${ }^{18}$ Mature women without children rarely escape their definition as children themselves: Electra typifies the oxymoron of the adult female child, unable to move beyond her traumatic childhood, while characters like Antigone and Polyxena reveal the vulnerability of girls who are not yet married, dying before they can assume maternal responsibilities. Medea, on the other hand, has already experienced the most crucial transitions in the female life-cycle, moving from childhood and virginity to sexual awakening and marriage (as she considers her union with Jason) and then to motherhood; through infanticide, however, she negates this natural progression, even as she asserts, ironically, her claim to heroic immortality. With this temporal reversal, in turn, Medea also negates the linear imperative of epic narrative, and replaces it with a pattern of repetition that functions both intertextually and metatextually. This pattern is in turn itself repeated in a dizzying multiplication of temporal dislocations in Ovid. ${ }^{19}$

\section{Back to the Future}

Ovid's exploration of Medea's maternity and the implications of its reversal for her literary career is clearly a response to and development not only of Euripides but also of Apollonius, the latter of whose Medea narrative is constructed as a "prequel" to the plot of Euripides' play. Apollonius narrates the events that precede Jason and Medea's 
life together as a couple, devoting the first two books of the poem to the voyage of the Argo and the second two books to Medea's encounter with Jason and the assistance she gives him, concluding with the departure from Colchis for the shores of Iolcus. Apollonius' narrative strategy has long been recognized as typical of Hellenistic poetry: in choosing to narrate the less familiar details of the story and to devote a great part of his narrative to the development of a love story instead, Apollonius exemplifies the Hellenistic preference for unusual and alternative versions of traditional tales..$^{20}$

The manner in which Apollonius moves the tragic Medea into an epic framework, furthermore, simultaneously gives concrete form to the narrative transgressiveness of her character and to his own transgressive epic. Apollonius' Medea is a girl, encountered just as she reaches marriageable age: he repeatedly calls her $\pi \alpha \rho \theta \dot{\varepsilon} v o \zeta$ and

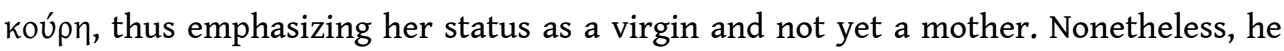
also uses imagery that casts her in a maternal role, thus drawing attention to the oxymoron of her virginal fertility. In response to Aeetes' demand for the return of his daughter from the Phaeacians, Medea pleads with queen Arete and the men in Jason's entourage for protection. To illustrate her emotional distress, Apollonius uses proleptic imagery to compare the virgin Medea with a recently widowed mother, who labors far into the night to provide for her children (Argon. 4.1060-67):

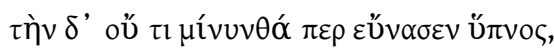

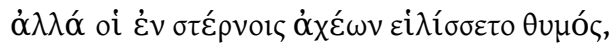

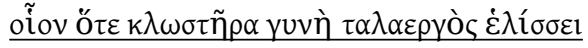

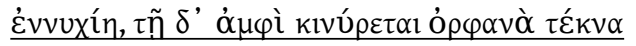

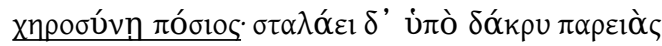

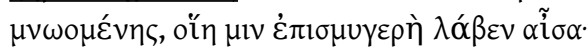

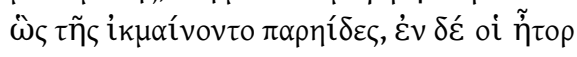

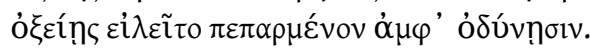

But sleep did not soothe her even a little,

but rather the powerful feeling of pains was whirled in her breast

just as when a wool-working woman whirls a spindle

through the night, and the fatherless children wail plaintively around her,

bereft as she is of her husband; and the tears drip down from her cheeks

as she remembers, such a gloomy fate has seized her;

thus were Medea's cheeks moistened, and the heart within her

was spinning, pierced about by sharp pains.

11 Apollonius anticipates her maternal destiny even earlier in the poem, when in Book 3 he compares her to a mother lamenting the death of her children, as if her future infanticide were already inscribed in the moment of infatuation (3.744-51):

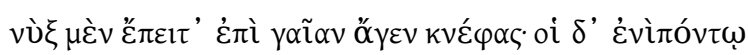

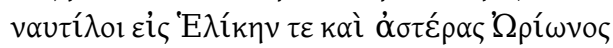

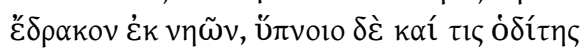

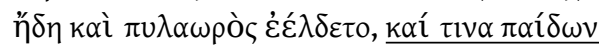

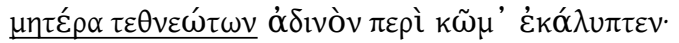

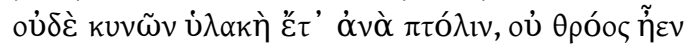

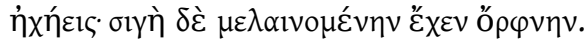

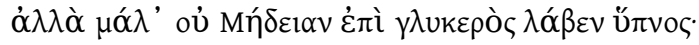

Night then drew darkness across the earth; on the sea, sailors

turned their eyes from their ships to Helice and the stars of Orion,

and both the traveler on the road and the doorkeeper were already

longing for sleep; and deep sleep surrounded the mother of children 
who have died.

Nor was there the barking of dogs any longer through the city,

no resounding noise; silence held the blackening darkness.

But indeed sweet sleep did not yet possess Medea ...

The childless Medea, whether virgin or infanticide, is rendered exceptional by her ability to transcend the narrative limits that are usually imposed on female experience in myth; accordingly, Apollonius suggests that, while not yet an epic figure, his Medea already possesses a narrative future that will make her part of the eternal world of epic. In moving from tragedy to epic, and from the role of wife and mother to that of marriageable virgin (and vice versa), Apollonius' Medea hints at an inexhaustible capacity to give birth, by means of a sort of narrative parthenogenesis, to numerous offspring in her image.

This unceasing generative ability comes to fulfillment in Ovid, who-like Medea herself -transgresses the boundaries of literary genres and so, metapoetically speaking, "gives birth" to multiple Medeas. For Ovid, Medea's infanticide makes her a byword for transgression-transgression that Ovid cleverly adapts to the subversive genre of erotic elegy. ${ }^{21}$ Her repeated appearances in Ovid's elegiac poetry both conform to elegiac conventions and experiment with rejecting them. Abandoned by Jason, Medea is the elegiac lover par excellence; at the same time, she assumes a role normally played by men, enslaved by their puellae and tormented by a love that is not reciprocal. ${ }^{22}$ When we read her monologue in Heroides 12, for example, we find her in the grip of grief and anger as she realizes that she has been abandoned. Medea takes advantage of the elegiac form of the epistle, exploiting it in order to portray herself as a defenseless victim. ${ }^{23}$ In fact, she claims that, even after her deployment of magical arts in Jason's defense, she has lost her usual expertise (Her. 12.163-66):

serpentes igitur potui taurosque furentes, unum non potui perdomuisse uirum;

quaeque feros pepuli doctis medicatibus ignes, non ualeo flammas effugere ipsa meas.

I was able to tame snakes and wild bulls; I could not tame this man alone.

I who repelled wild flames with my learned potions am unable myself to flee the flames of my passion.

Medea's inability to protect herself recalls the lament of Catullus, seeking relief from the disease caused by amatory betrayal (76.7-8)..$^{24}$ In Medea's case, of course, no external source of medicina would appear to be necessary; ${ }^{25}$ nonetheless, she recognizes the inability of her magic unguents to make her invulnerable to the fire of love (Her. 12.168), and instead assumes the role of a thwarted victim. ${ }^{26}$ She also does not exploit her divine heritage to assert physical and emotional control over Jason. While Euripides portrays Medea as something other than a typical woman in love, especially when she effectively appears as a dea ex machina in the final scene of the play, for both Apollonius in the Argonautica and Ovid in Heroides 12 she is for all intents and purposes mortal. Like Apollonius before him, Ovid exploits Medea's feminine gender in all its presumed weakness, timidity, and impressionability to provoke our sympathy for her. Ovid articulates Medea's situation in terms that recall other women first loved and then abandoned-women whose situation merges that of the controlling dominae of elegy ${ }^{27}$ with that of the tragically abandoned reginae of epic and epyllion, especially Catullus' Ariadne and Virgil's Dido-foreign women, who in betraying their families 
provide the men who abandon them with a convenient justification for their actions. This Medea represents herself in her apparent powerlessness as suited to the genre of elegy.

A crucial component in Ovid's construction of Medea as an elegiac character is the almost complete absence of her children from her monologue until past its midpoint. Elegiac characters do not, for all intents and purposes, have families; marriage itself is an inconvenience in the elegiac world, of value only as representative of a social norm that must be violated. ${ }^{28}$ Of course, many of the characters whose voices are heard in the Heroides address their letters to an absent spouse or would-be spouse, including the most paradigmatically faithful wife of all, Penelope (Heroides 1); but the repeated pattern of a partner's absence, with its intimations of forgetfulness and/or betrayal, insures that the women whose letters we read are consigned by their shared abandonment to a permanent elegiac condition. Children are even less congenial to the world of elegy than are husbands, symbolizing as they do an ideological stability of sex and gender roles. ${ }^{29}$ In the story of Medea, however, children are clearly essential, as they provide the means for her revenge against Jason; their importance in signifying her maternity-and so, the shock-value of infanticide-is underscored in Euripides' play when Medea appears aloft in the exodos, the two corpses at her feet (Med. 1314-22). Ovid, on the other hand, draws attention to their existence primarily through dark and ironic allusions; unlike a tragedy, the letter denies them a physical presence. He thus manages both to sustain her elegiac portrait and to develop an unfulfilled sense of foreboding that delays indefinitely her tragic action.

The allusions to the children by Ovid's Medea are both pathetic and calculating. At Her. 12.135-36, she combines an allusion to her exile with the first explicit mention of her companions, the two children, and so ironically echoes her departure with the children's bodies in the chariot as enacted in the Euripidean exodos. Ovid revises the Euripidean scene, however, with a detail that is both grotesque and, at least in elegiac terms, a cliché, by giving her a third companion, amor-or, as Federica Bessone suggests, Amor, a familiar personification from elegy ${ }^{30}$ : "at your command I withdrew from the house in the company of the two children and of my love for you, which attends me always" (iussa domo cessi natis comitata duobus / et, qui me sequitur semper, (A)more tui). The pathos aroused by Medea's allusion to exile continues as she recalls how she learned about Jason's impending marriage to Creusa, her willful ignorance forcefully dispelled when the younger of her two children observes the bridal procession (147-52) $)^{31}$ :

me quoque, quidquid erat, potius nescire iuuabat; sed tamquam scirem, mens mea tristis erat, cum minor e pueris, iussus studioque uidendi, constitit ad geminae limina prima foris:

hinc mihi 'mater, adi! pompam pater' inquit 'Iason ducit et adiunctos aureus urget equos!'

For me too it was preferable not to know whatever it was; but as if I did know, my mind was in mourning,

when the younger of the children, eager to see and ordered to do so, took a stand right at the threshold of the double doors.

From here he said to me, "Come, mother! My father Jason, all in gold, is leading a procession and is driving a team of horses!" 
The vivid recollection by the mother of her child's innocent words, together with her specification that the speaker was the younger of the two, underscores both her maternal instincts and her isolation-she, and we, know what must happen; the child, on the other hand, does not.

Medea's tenderness as a mother-and simultaneously, the vulnerability of the children -becomes most explicit as she approaches the end of her letter to Jason with a lament for their lost love (187-92, 197-98):

si tibi sum uilis, communes respice natos: saeuiet in partus dira nouerca meos.

et nimium similes tibi sunt, et imagine tangor, et, quotiens uideo, lumina nostra madent.

per superos oro, per auitae lumina flammae, per meritum et natos, pignora nostra, duos:

te peto, quem merui, quem nobis ipse dedisti, cum quo sum pariter facta parente parens.

If I am of no value to you, at least consider the children we share: a wicked stepmother will rage against my offspring.

They are too much like you! I am touched by the image, and as often as I see them, my eyes grow wet.

By the gods above, by the light of my grandfather's flame, by my service to you and by the two children, symbols of our shared trust:

I ask for you, you on whose gratitude I have earned a claim, you who gave yourself to me, you with whom I share the role of parent.

Medea's loss and his betrayal are given immediacy through the physical existence of their children, embodiments of Jason's lack of faith and of the risk his betrayal entails. Medea uses the existence of the children as manifestations of the pathetic condition in which she now finds herself, even as, through a kind of "double-speak," her words hint at a violent rupture. ${ }^{32}$ Particularly ironic is her reference to a cruel stepmother (dira nouerca), ${ }^{33}$ implying that Creusa will harm the children: Medea thus draws explicit attention to the potential destructiveness of an alternative maternal figure even as she calls herself parens while approaching the end of both the letter and her identity as mother. ${ }^{34}$

Before we proceed to the end of the letter, however, let us glance back at its beginning. The rhetorically abrupt and even argumentative opening of the poem brings the reader up short: "But in fact, I recall, as queen of the Colchians I was available to you ..." (At tibi Colchorum, memini, regina uacaui, Her. 12.1). Struck by the use of at as the first word in Medea's letter, scholars have regularly noted the intertextual echo here of the first line of Aeneid 4, where Dido yields to her desire for Aeneas and is then betrayed by him: "But in fact, the queen, for some time now wounded by intense desire ..." (At regina graui iamdudum saucia cura). ${ }^{35}$ The force of this intertextual link can be seen to extend even further, however: the word regina is a strange way for Ovid to refer to Medea, and an even stranger way for her to refer to herself, since in fact she is not, and never was, the queen of Colchis; to be precise, she is first the daughter of a king and later the partner of a would-be king, rejected by the latter when the woman who could in fact become his queen arrives on the scene. The broad sense in which the word regina is used here looks back not only to Dido but to another Virgilian model, appearing in the 
context of a description of the scene on the doors of the temple of Apollo at Delphi. They are the handiwork of Daedalus, who uses them to depict some of his earlier achievements, especially those on Crete: the ecphrastic description of these doors evokes both Daedalus' labyrinth and Theseus' battle with the Minotaur, and the illicit desires of two women are an essential part of the two narratives thus juxtaposed: "But pitying indeed the great love of the queen ..." (magnum reginae sed enim miseratus amorem, Aen. 6.28). Because Daedalus' handiwork involves two related but distinct episodes, Virgil's allusion to "the love of a queen" as an inspiration for Daedalus contains a studied ambiguity: is Daedalus thinking of Pasiphaë, the queen of Crete, or of her daughter Ariadne, not yet a queen herself but her mother's legitimate heir? ${ }^{36}$ When Ovid's Medea uses the word regina to describe herself, then, she evokes a virtual genealogical paradigm that locates her on a literary map, ${ }^{37}$ and with the word "memini," she makes explicit a knowing and self-reflexive echo of her literary models. ${ }^{38}$ These models also confirm the generic transformation Ovid has effected in introducing Medea into the Heroides: like them, she embodies the conflicting values of epic and elegy.

Her opening allusion to memory reminds Ovid's reader that Medea has a past in other literary contexts; conversely, at the close of her letter, several features prefigure her future, and in so doing they signal the impossibility of closure that her generic transformation entails. In Medea's final three couplets, the rhetorical device of aposiopesis, the use of the future tense, and the imagery of birth ${ }^{39}$ all mark the incompleteness of the action (207-12):

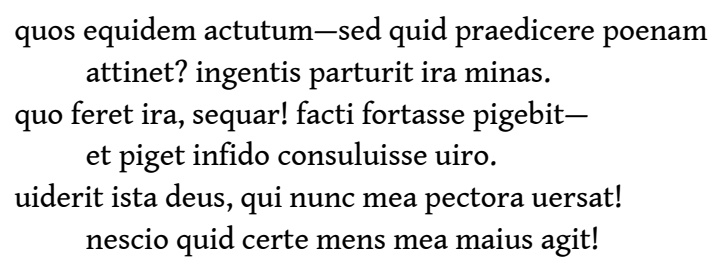

Indeed, soon - but what is the use of proclaiming the punishment beforehand? My wrath is pregnant with enormous threats.

Where wrath leads I shall follow! perhaps I will regret the acteven now I regret having looked after the interests of a faithless man.

Let the god who now causes turmoil in my heart see to it! Something greater, surely, my mind intends!

Medea is just beginning to hint at the revenge she intends for the members of Jason's new family, but now she interrupts herself mid-sentence (quos equidem actutum-, 207). Aposiopesis allows Medea to leave unsaid a crucial detail in the sequence of events: quos refers to Creon and Creusa, as well as to Jason himself-in other words, to the objects of her vengeance both past and future. It is also a strikingly dramatic effect; this is a theatrical statement, not the carefully chosen language of a text intended to be read. ${ }^{40}$ The evocation of drama thus created is reinforced by her use of the word actutum, fundamentally a marker of archaic Roman tragic language. ${ }^{41}$ Its appearance at this climactic moment gestures to her theatrical altera ego, both in Euripides (and his successors) and in Ovid. The pointed interest Ovid shows here in the timing of the letter's conclusion reinforces the sense that Medea's story is far from over: a combination of verbs in the future tense (feret; sequar; pigebit) and of words and expressions that encourage her readers to expect a continuation of the action (praedicere; parturit; uiderit; nescio quid ... maius) make this letter a prelude rather than a denouement to her fulfillment of a heroic destiny. 
Medea is a misfit as an elegiac puella, then, in spite of her familiarity with the conventions of the genre; she uses the close of her letter, therefore, to look forward to a more elevated destiny, as a figure of tragedy or of epic. But even in these genres, as she knows, her gender limits her; roles like that of Penelope or even Antigone cannot contain her aspirations. In the final lines of her letter, therefore, Medea anticipates a new kind of self, that will liberate her from the burden of maternity and that will bring her poetic immortality. The periphrasis nescio quid ... maius in the final line occurs on one other occasion in Augustan poetry, in Propertius' description of Virgil's forthcoming epic poem, not yet complete but destined to be greater than the Iliad itself: "make way, Roman writers! Make way, Greeks! | something greater than the Iliad is being born" (cedite Romani scriptores, cedite Grai! | nescioquid maius nascitur Iliade, Prop. 2.34.66). ${ }^{42}$ Hardie has identified "the end that is also a beginning" as a typical characteristic of the totalizing tendency of epic narrative, particularly evident in Virgil, whose Aeneid begins with the end of the Trojan War and ends with the eternal destiny of Rome. ${ }^{43}$ With her concluding promise of "something greater" (nescioquid maius), Ovid's Medea foresees an epic narrative in which, upon killing her children, she will begin her heroic career. ${ }^{44}$ As she steels herself and us for her passage from word to action (agit, 212), she also redefines what it means to give birth: whereas Propertius had alluded to the impending arrival of the Aeneid with an impersonal, almost abstract use of the image of birth (nascitur), Ovid uses the image in a terrifyingly aggressive way: for Medea, giving birth is the result of wrath, ira-a telling echo of the first word of the Iliad; in turn, wrath's natural offspring are not human children, but great threats of force: ingentis ira parturit minas (208). ${ }^{45}$ The elegiac Medea knows that when her threats are carried out, she will be childless, and ready to enter the company of heroes. She has also prepared herself-and us-to rupture the strictures of elegy and to assume a central role in the world of epic.

\section{Becoming Medea}

The Medea who emerges from Heroides 12 dominates the first half of Book 7 of the Metamorphoses. ${ }^{46}$ Many scholars have detailed both the dramatic character of this Medea and her indebtedness to that of Apollonius, and have noted her dependence on the treacherous women, later abandoned, of earlier Latin literature, especially Ariadne and Dido. ${ }^{47}$ The Medea of the Metamorphoses, however, both combines and confounds the categories of literary genre: she combines elements of epic and tragedy along with remnants of her elegiac past, and the emotional torment felt by her characterespecially her dilemma regarding the respective merits of rectum, pietas, and pudor (Met. $7.72)^{48}$ on the one hand and on passion, ardor (7.76), on the other ${ }^{49}$-places this generic confusion center-stage. Should we consider Medea a victor, or a victim? And which of these roles should she choose for herself? Should she destroy others, or destroy herself? These questions in turn suggest how Medea's challenge to the limits of genre entails a second challenge, to the limits of gender. Both pudor and ardor are typical, even predictable, manifestations of emotion in a young girl overpowered by desire; rectum, on the other hand, is profoundly moralizing, ${ }^{50}$ and pietas is a "buzzword" that evokes first and foremost the masculine world of epic values, especially for a public raised on the Aeneid..$^{51}$ The internal conflict that stirs Medea is precisely the same as that which torments Aeneas when he debates the merits of civic and social obligations 
on the one hand and of personal desire on the other, although in Medea's case even her sense of obligation is fundamentally personal. The very fact of her centrality in the narrative of the Metamorphoses endows her with a degree of epic masculinity; following in Apollonius' footsteps, furthermore, Ovid has downplayed the role of Jason in this episode almost to the vanishing point. And even when we do see him, we see him through the eyes of Medea; she is the character around whom the story revolves.

Apart from discussing Apollonius' role in determining the shape of Ovid's narrative, scholars usually comment on the virtual invisibility in the Metamorphoses of Medea's most famous, and infamous, act, the infanticide; in the first half of the book (7.1-424), centered entirely on Medea, the episode at Corinth is reduced to a four-line summary near the end of the story (7.394-97) ${ }^{52}$ :

sed postquam Colchis arsit noua nupta uenenis

flagrantemque domum regis mare uidit utrumque, sanguine natorum perfunditur impius ensis,

ultaque se male mater Iasonis effugit arma.

But after the new bride blazed with Colchian potions

and the sea on each side of Corinth witnessed the burning house of the king,

the criminal sword is bathed in the blood of the children,

and having avenged herself evilly the mother fled from Jason's weapons.

This summary is reasonably faithful to the plot of Euripides' play, aside from the burning palace of Creon, an added detail that expands upon the allusion in the preceding line to the "burning" of Jason's new bride (arsit). The second two verses in particular offer an exceptionally succinct review of the action, with virtually every word contributing to a rehearsal of Euripides' exodos; the dead children come first in 396, followed by the weapon of their destruction; and 397 begins with revenge (ulta) and ends with the flight from Jason (Iasonis effugit arma). On this last line of the four, commentators generally note that the adverb male should be construed with the participle ulta (and I have done so in my translation); ${ }^{53}$ but, as E.J. Kenney remarks, "the order of the words suggests that male refers also to mater ... 'a denaturalized mother." 54 Kenney's comment points to a fundamental paradox in the story itself: with her children dead, Medea, their mother, is a mother no longer; the normal (i.e., stereotypical) course of affairs, in which children are raised and protected by their mothers so that they can eventually step into the parental role themselves, has been replaced by a narrative-the surrounding narrative in Metamorphoses 7-in which Medea carries out an act of revenge that resembles a sort of epic masculinity even as she reverses narrative time by returning to the status of a childless woman.

The temporal disharmony of the Medea episode takes several forms. While the superficial narrative proceeds in reasonably straightforward manner (i.e., from Colchis to Athens, with all the usual intermediate stops), the theme of this narrative is repetitive and redundant. ${ }^{55}$ Medea repeatedly calls on Hecate $(74-75,94-95,174-78$, 194-95, 241); she travels repeatedly (220-37, 350-93; 398-402); she puts her magic, often destructive, always disturbing, to work on numerous occasions (98-99, 115-16, 137-38, 149-53, 189-91, 199-206, 238-50, 257-78, 312-21, 326-30). And just as she escapes from Corinth and Jason at 7.397 (effugit), so she escapes a second time from Athens and Aegeus at 7.424 (effugit)-and simultaneously, from Ovid's poem, as this escape is the last thing we hear about Medea in the Metamorphoses..$^{56}$ It should come as no surprise, then, that this final escape is made possible through carmina: "she fled the murder in 
clouds stirred by her magic" (effugit illa necem nebulis per carmina motis), in a play on words that glances, but with the utmost subtlety, at an equation between the sorcerer Medea and the poet Ovid: her magic is also his. ${ }^{57}$

But repetition is not the only form of temporal interference in this episode; far more striking is the temporal reversal effected by Medea's magic, especially when she agrees with Jason's request to rejuvenate Aeson, a procedure described by Ovid in elaborate detail (159-293). At first Jason suggests a zero-sum intervention, asking her to take some years from him and give them to his father instead (164-68). The fungibility of time thus proposed is rejected by Medea, who refers to the idea as "a crime" (scelus, 172) and so implies that such an exercise of her skills is anathema to her; instead, she proposes to ask Hecate for help in effecting the rejuvenation of Aeson as a gift to Jason (176-78). The first real suggestion she gives of her ability to interfere with linear time, however, appears only in her nighttime prayer to Hecate and all the other divinities of night, in the list of otherworldly accomplishments made possible with their help: she can make rivers reverse their natural course and return to their source (199-200). ${ }^{58}$ This reversal of the natural order of things becomes fully realized after she seeks out the plants and roots that she will use for her potion, and performs an elaborate ritual sacrifice involving these materials and many others (stones, owls' wings, the innards of a werewolf, a deer's liver, and the heads and beaks of old crows, among other things); the end result, after a successful demonstration of her powers with the rejuvenation of an olive branch (279-84), is the rebirth of Aeson as a young man, strong and handsome, reminiscent of the man he was forty years earlier (287-93):

... quos postquam combibit Aeson

aut ore acceptos aut uulnere, barba comaeque

canitie posita nigrum rapuere colorem,

pulsa fugit macies, abeunt pallorque situsque,

adiectoque cauae supplentur corpore rugae,

membraque luxuriant. Aeson miratur et olim

ante quater denos hunc se reminiscitur annos.

After Aeson had drunk down these things,

taken in either by mouth or by the open wound, his beard and his hair

lost their whiteness and took on a black color,

his thinness, beaten off, flees, his pallor and old age depart,

his deep wrinkles are filled with added flesh,

and his limbs flourish. Aeson marvels, and

recalls his own self like this from forty years ago.

In referring to Aeson as he looked forty years earlier, Ovid is explicit about the temporal reversal effected by Medea; simultaneously, Ovid demonstrates his own ability to play with time, presenting Medea's preparations first of all in painstaking detail and extending over more than 100 verses, and then speeding up the narrative so that Aeson's rejuvenation seems to occur "in the blink of an eye," as Kenney notes..$^{59}$ And as time seems to expand or contract, or even to reverse itself, at the behest of Medea (and of her poet, Ovid), a stray detail in the narrative invites reconsideration. In her journey to find a variety of plants and roots, Medea had used her snake-drawn chariot-the same vehicle with which, in "future reflexive" terms, ${ }^{60}$ she has not yet escaped from Corinth (the infanticide is yet to occur) but which looks back to Euripides' deus ex machina; and these snakes, old as they are, are rejuvenated by the fragrance of Medea's gatherings ${ }^{61}$ and so shed their skin: "nor were the snakes touched except by 
the odor, and yet they still shed the ancient skin of their old age" (neque erant tacti nisi odore dracones, | et tamen annosae pellem posuere senectae, Met. 7.236-37). limit her ability to reproduce-but the form of reproduction she claims for herself adds to her power, rather than limiting it. The imagery of reproduction takes on physical form in Ovid's description of Jason's triumphant acquisition of the golden fleece, made possible by Medea's creation of medicamina (7.116) that protect Jason from the firebreathing bulls that bar access to the fleece. After their defeat, Jason faces a second challenge: he must sow serpents' teeth in the ground and confront the resulting crop of armed warriors. The emergence of these men from the earth is compared by Ovid to the birth of an infant from its mother's womb (7.123-30):

$$
\begin{aligned}
& \text { semina mollit humus ualido praetincta ueneno } \\
& \text { et crescunt fiuntque sati noua corpora dentes; } \\
& \text { utque hominis speciem materna sumit in aluo } \\
& \text { perque suos intus numeros componitur infans } \\
& \text { nec nisi maturus communes exit in auras, } \\
& \text { sic ubi uisceribus grauidae telluris imago } \\
& \text { effecta est hominis, feto consurgit in aruo, } \\
& \text { quodque magis mirum est, simul edita concutit arma. }
\end{aligned}
$$

The earth softens the seeds pretreated with a strong potion, and once sown, the teeth grow and become new bodies; and just as an infant takes on the appearance of a human in his mother's womb and is completed in every detail and does not emerge into the shared breezes until he is ready, thus, when the image of a human was created in the womb of the pregnant earth, it rose up in the productive field, and, even more amazing, it immediately brandished the weapons thereby produced.

The mythical trope that makes Earth a mother and the sexual stereotype that imagines intercourse between a male and a female as analogous to plowing and sowing a field are both combined and inverted here ${ }^{63}$ : plowed and sown (aratos spargit in agros, 122), the soil softens and germinates the seeds to which Medea has applied an ointment; and, just as an infant develops in its mother's womb and emerges at maturity, so images of men rise up from the impregnated soil-and brandish weapons.

Medea herself grows pale at the thought of what these "children" could do to Jason: "as she saw the youth, all alone, being attacked by so many enemies, she grew pale and sat, 
chilled and with the blood drained suddenly from her face" (utque peti uidit iuuenem tot ab hostibus unum, | palluit et subito sine sanguine frigida sedit, 7.135-36), and so adds an additional charm (carmen / auxiliare, 137-38) to her powerful magic; it is precisely this that leads to Jason's triumph. Within a few more verses, the "earthborn brothers" (terrigenae fratres, 141), having turned their weapons against each other in civil strife, fall in the line of battle. Medea thus goes from momentary weakness to a repetition of her powerful magic, using her carmen to bring about the killing of the newborn warriors by Jason, and so to ensure both the continuation of her story and the inevitable infanticide that awaits. This action not only repeats the earlier use of magic in this episode but also sends us back to Medea's first infanticide, in Euripides, in an unending cycle of destruction and creativity. Ovid's epic Medea is forever and always becoming the transcendent character she is destined to be, although not even epic can wholly contain Medea.

\section{Medea's Impossibility}

In Ovid's Medea, creative and destructive powers go hand in hand. The magic through which she can invert or reverse the course of nature is the possession that allows her to control time itself; her rejuvenation of Aeson, and the accompanying rejuvenation of her snakes, are unmistakable doublets for her own renewal. Likewise, her children are essential to her self-definition, since they alone enable her to embody a living oxymoron, the childless mother whose deeds and accomplishments permit her to transcend the gendered world of elegy and embark upon an epic career. Medea's fertile maternity is key to her survival; indeed, it constitutes her assertion of immortality. And her survival, both in and outside of texts, suggests that through a combination of temporal and ideological reversals, a determined striving for nescioquid ... maius, and the power of carmen itself, the adunaton imagined by the chorus of Corinthian women in the first stasimon of Euripides' play has been transformed into the possible. Ovid suggests that Medea herself is the embodiment of "a new genre of poetry" imagined by Zeitlin and detected by Hopman ${ }^{64}$ in the conclusion of Euripides' play-not however as revenge tragedy suited to women, and not even as an elegiac woman, but as an otherwise impossible instantiation of epic in the feminine voice, regenerating itself on end.

Of course, it goes without saying that Medea's gendered claim to epic stature is not unproblematic: in a genre that can be defined, as Ennius says, as maxima facta patrum (Epigr. 45 Courtney), ${ }^{65}$ the infanticide of Medea is in perennial conflict with the ideology of continuity that sustains heroic epic. When Ennius refers to the protagonists of epic as patres, he acknowledges the obvious significance of succession in the formation of epic narrative; but when Ovid's Medea acts in epic, she creates, if only for a brief time, a very different type of poetry, focusing not on succession but on the violent annihilation of all around her as a means to achieve her own rebirth. Yet in the final analysis, the poetic world that Medea inhabits is as irretrievable as is her desire for heroic stature: her abrupt escape from Metamorphoses 7 (at 424, quoted above) takes both her and us into the unknown, a place in which to imagine a new genre that validates Medea's gender. As for Ovid, however, so for us: the route that grants access to this terrain leads only to uncharted territory. ${ }^{66}$ 


\section{BIBLIOGRAPHY}

Barchiesi, A. 1993. "Future Reflexive: Two Modes of Allusion and Ovid's Heroides." HSCP 95: 333-65.

Battistella, C. 2015. “Medea Reaches Maturity: On Ovidian Intertextuality in Sen. Med. 905-15." CJ 110: 446-70.

Bessone, F. 1995. "Medea's Response to Catullus: Ovid, Heroides 12.23-4 and Catullus 76.1-6." CQ 45: 575-78.

ed. 1997. P. Ovidi Nasonis Heroidum Epistula XII Medea Iasoni. Florence : Felice Le Monnier.

Binroth-Bank, C. 1994. Medea in den Metamorphosen Ovids: Untersuchungen zur ovidischen Erzähl- und Darstellungsweise. Frankfurt: P. Lang.

duBois, P. 1988. Sowing the Body: Psychoanalysis and Ancient Representations of Women. Chicago: University of Chicago Press.

Bömer, F., ed. 1976. P. Ovidius Naso: Metamorphosen Buch VI-VII. Heidelberg: Carl Winter.

Boyd, B.W. 2016. "Ovid's Circe and the Revolutionary Power of carmina in the Remedia amoris." In A. Keith and J. Edmondson, eds., Roman Literary Cultures: Domestic Politics, Revolutionary Poetics, Civic Spectacle, 111-23. Toronto: University of Toronto Press.

2017. Ovid's Homer: Authority, Repetition, and Reception. New York: Oxford University Press.

Boyle, A.J. 2012. “Introduction: Medea in Greece and Rome." Ramus 41: 1-32.

Casali, S. 1995. “Aeneas and the Doors of the Temple of Apollo." CJ 91: 1-9.

Courtney, E., ed. 1993. The Fragmentary Latin Poets. Oxford: Oxford University Press.

Curley, D. 2013. Tragedy in Ovid: Theater, Metatheater, and the Transformation of a Genre. Cambridge: Cambridge University Press.

Demand, N.H. 1994. Birth, Death, and Motherhood in Classical Greece. Baltimore: Johns Hopkins University Press.

Easterling, P.E. 2003. “The Infanticide in Euripides' Medea.” In J. Mossman, ed., Oxford Readings in Classical Studies: Euripides, 187-200. Oxford: Oxford University Press (revised version of YCS 25: 177-91).

Foley, H.P. 2001. Female Acts in Greek Tragedy. Princeton: Princeton University Press.

Fulkerson, L. 2005. The Ovidian Heroine as Author: Reading, Writing, and Community in the Heroides. Cambridge: Cambridge University Press.

2013. "Seruitium amoris: The Interplay of Dominance, Gender, and Poetry." In T.S.

Thorsen, ed., The Cambridge Companion to Latin Love Elegy, 180-93. Cambridge: Cambridge University Press.

Fulkerson, L., and T. Stover, eds. 2016. "Introduction: Echoes of the Past." In L. Fulkerson and T. Stover, eds., Repeat Performances: Ovidian Repetition and the Metamorphoses, 3-27. Madison, WI: University of Wisconsin Press.

Gardner, H.H. 2013. Gendering Time in Augustan Love Elegy. Oxford: Oxford University Press Goldberg, S. and G. Manuwald, eds. 2018. Fragmentary Republican Latin, Volume II: Ennius: Dramatic Fragments; Minor Works. Cambridge, MA: Harvard University Press. 
Graf, F. 1997. "Medea, the Enchantress from Afar: Remarks on a Well-Known Myth." In J.J. Clauss and S.I. Johnston, eds., Medea: Essays on Medea in Myth, Literature, Philosophy, and Art, 21-43. Princeton: Princeton University Press. 2009. Apollo. London: Routledge.

Guastella, G. 2000. "Il destino dei figli di Giasone (Euripide, Ovidio, Seneca)." In B. Gentili and F. Perusino, eds., Medea nella letteratura e nell'arte, 139-75. Venice: Marsilio.

Hardie, P. 1993. The Epic Successors of Virgil: A Study in the Dynamics of a Tradition. Cambridge: Cambridge University Press.

Heinze, T. 1991-93. “The Authenticity of Ovid Heroides 12 Reconsidered.” BICS 38: 94-97. ed. 1997. P. Ovidius Naso, Der XII. Heroidenbrief: Medea an Jason. Mit einer Beilage: Die Fragmente der Tragödie Medea. Leiden: Brill.

Hinds, S.E. 1993. "Medea in Ovid: Scenes from the Life of an Intertextual Heroine." MD 30: 9-47. 2011. “Seneca's Ovidian Loci." SIFC 9: 5-63.

Hopman, M. 2008. “Revenge and Mythopoiesis in Euripides' Medea.” TAPA 138: 155-83.

Hunter, R.L., ed. 1989. Apollonius of Rhodes: Argonautica Book III. Cambridge: Cambridge University Press.

Jacobson, H. 1974. Ovid's Heroides. Princeton: Princeton University Press.

James, S. 2003. Learned Girls and Male Persuasion. Berkeley: University of California Press.

Keith, A. 2000. Engendering Rome: Women in Latin Epic. Cambridge: Cambridge University Press.

Kennedy, D.F. 2012. “Love's Tropes and Figures." In B.K. Gold, ed., A Companion to Roman Love Elegy, 189-203. Malden, MA: Wiley-Blackwell.

Kenney, E.J. 2001. “Est deus in nobis: Medea Meets her Maker.” In T.D. Papanghelis and A. Rengakos, eds., A Companion to Apollonius Rhodius, 261-83. Leiden: Brill. ed. 2011. Ovidio, Metamorfosi: Volume IV (Libri VII-IX). Milan: Fondazione Lorenzo Valla.

Knox, B.M.W. 1977. “The Medea of Euripides.” YCS 25: 193-225.

Knox, P. 1986a. "Ovid's Medea and the Authenticity of Heroides 12." HSCP 90: 207-23. . 1986b. Ovid's Metamorphoses and the Traditions of Augustan Poetry. Cambridge: Cambridge Philological Society.

Lefkowitz, M. 2007. Women in Greek Myth. 2nd ed. Baltimore: Johns Hopkins University Press.

Lindheim, S.H. 2003. Mail and Female: Epistolary Narrative and Desire in Ovid's Heroides. Madison, WI: University of Wisconsin Press.

Loraux, N. 1993. The Children of Athena. Trans. C. Levine. Princeton: Princeton University Press.

Manuwald, G. 2013. “Medea: Transformations of a Greek Figure in Latin Literature.” G\&R 60: 114-35.

Martina, A., ed. 2018. Euripide, Medea. Three volumes. Pisa: Fabrizio Serra Editore.

Mastronarde, D.J., ed. 2002. Euripides: Medea. Cambridge: Cambridge University Press.

McAuley, M. 2016. Reproducing Rome: Motherhood in Virgil, Ovid, Seneca, and Statius. Oxford: Oxford University Press.

Miller, J. 1993. “Ovidian Allusion and the Vocabulary of Memory.” MD 30: 153-64. 
Newlands, C.E. 1997. “The Metamorphosis of Ovid's Medea.” In J.J. Clauss and S.I. Johnston, eds., Medea: Essays on Medea in Myth, Literature, Philosophy, and Art, 178-208. Princeton: Princeton University Press.

Petersen, L.H. and P. Salzman-Mitchell. 2012. "Introduction: The Public and Private Faces of Mothering and Motherhood in Classical Antiquity." In L.H. Petersen and P. Salzman-Mitchell, eds., Mothering and Motherhood in Ancient Greece and Rome, 1-22. Austin, TX : University of Texas Press.

Quint, D. 1991. "Repetition and Ideology in the Aeneid." MD 24: 9-54.

Ricks, C. 1976. "Allusion: The Poet as Heir.” In R.F. Brissenden and J.C. Eade, eds., Studies in the Eighteenth Century, III, 209-40. Toronto: University of Toronto Press.

Rosati, G. 1988. "Il parto maledetto di Medea (Ovidio, Her. 6, 156 s.)." MD 21: 305-9. 1990. "Note al testo delle Heroides." MD 24: 161-79.

Schmitzer, U. 2003. “Ovid und seine Medea." In R. Kussl, ed., Spurensuche, 21-48. Munich: Bayerischer Schulbuch Verlag.

Sharrock, A. 1994. Seduction and Repetition in Ovid's Ars Amatoria II. Oxford: Oxford University Press.

Spoth, F. 1992. Ovids Heroides als Elegien. Munich: C.H. Beck.

Trinacty, C. 2007. “Seneca's Heroides: Elegy in Seneca's Medea.” CJ 103: 63-78.

Visser, M. 1986. “Medea: Daughter, Sister, Wife, Mother. Natal Family versus Conjugal Family in Greek and Roman Myths about Women." In M. Cropp, E. Fantham, and S.E. Scully, eds., Greek Tragedy and its Legacy: Essays Presented to D.J. Conacher, 149-65. Calgary: University of Calgary Press. Williams, G. 2010. “Apollo, Aesculapius and the Poetics of Illness in Ovid's Metamorphoses.” PLLS 14: 63-92.

2012. "Medea in Metamorphoses 7: Magic, Moreness and the Maius Opus." Ramus 41: 49-70.

Wofford, S. 1992. The Choice of Achilles: The Ideology of Figure in the Epic. Stanford: Stanford University Press.

Zeitlin, F.I. 1996. Playing the Other: Gender and Society in Classical Greek Literature. Chicago: University of Chicago Press.

\section{NOTES}

1. See Mastronarde 2002 on 419-24; Martina 2018, vol. 3 on 419-30. As both commentators remark, the chorus' claim of poetic misogyny overlooks the distinguished female poets whose names and works would have been known to the Athenian audience, but the generalizing stereotype nonetheless holds true. More generally on Hesiod and Semonides on women, see Loraux 1993: 72-110.

2. Zeitlin 1996: 348; cf. B.M.W. Knox 1977: 223 on the radical nature of this chorus.

3. Hopman 2008.

4. Hopman 2008: 180.

5. Hopman 2008: 175-80 makes a strong case for reading the Oresteia as an intertext for Euripides' play, providing a model for the perfect tragic revenge plot. 
6. The two verses are fr. 1, seruare potui, perdere an possim, rogas? (Quint. IO 8.5.6) and fr. 2, feror huc illuc, uae, plena deo (Sen. Suas. 3.5-7). See Heinze 1997: 221-52 for a discussion of the fragments and hypothetical reconstruction of the play; also Curley 2013: 41-43.

7. Curley 2013: 37-58 argues that Ovid must have written the Medea immediately after completing the Amores, and that he went on to the Heroides only thereafter; he reads these epistolary poems as an experiment with how to combine tragic and elegiac features in a new form. While his argument is ingenious, it is also highly speculative. Since the focus of this essay does not depend on the relative chronology of Ovid's works, I refrain from discussing Curley's theory further here. I also note that Heroides 12 has been the subject of periodic challenges to its authenticity: see P. Knox 1986a; also Heinze 1991-93. While Knox' discussion contains many valuable observations about the diction and style of the poem, I am convinced by more recent studies that this poem is very likely to be the work of Ovid, and I will treat it as such in this essay.

8. On the importance of Ovidian repetition, see now Fulkerson and Stover 2016 and Boyd 2017: 8-10, 213-15. For a survey of the many Medeas in Latin literature, see Boyle 2012, Manuwald 2013, and Martina 2018, vol. 1: 83-107.

9. See Mastronarde 2002 and Martina 2018, vol. 3, ad loc.

10. B.M.W. Knox 1977 and Easterling 1977 have shaped subsequent scholarship on the character of Medea and the interpretation of the play generally; cf., e.g., Zeitlin 1996: 60 and 348; Foley 2001: 257-68 on Medea's “divided self"; Mastronarde 2002: 36 on "Medea's appropriation of masculine values"; and Martina 2018, vol. 1: 219-21 on "lo status mascolino di Medea."

11. Cf. Wofford 1992: 7: "From the Iliad on, the disjunction between the represented action of characters in epic . . . and the figurative claims made about that action by the poet becomes a defining feature of epic poetry, bringing to the epic an ideological and moral ambivalence that comes from its simultaneous articulation of two contrasting claims about the value of heroic action (as each poem defines it)."

12. Hardie 1993, following Ricks 1976. See now also Boyd 2017: 75-180 on Ovid's appropriation of the paternity trope.

13. On the cultural significance of family and marriage in other versions of the story of Medea, see Visser 1986 and Guastella 2001; for a broader reading of the topic and its Roman implications, see McAuley 2016: 139-42.

14. See Mastronarde 2002: 30, 38-40 on the staging of this scene.

15. Hopman 2008: 175-80; the quoted phrase is from 176.

16. Barchiesi 1993: 334: "But what happens when the older [literary] tradition enters a new text as a view of the future? ... The literary tradition-a source of power, control, and anxiety, a perfect analogy for the past in everyone's life-is now displaced, and a potential for irony opens up."

17. Trinacty 2007 and Battistella 2015: 447-48 expand upon this theme as developed by Seneca, following Ovid; see also McAuley 2016: 207-27.

18. On Greek mothers, Demand 1994 remains the most comprehensive study in English. See also Visser 1986; Loraux 1993; Petersen and Salzman-Mitchell 2012; cf. also Lefkowitz 2007:106-21 on the mythological portrayal of "the woman without men." On Roman mothers as depicted in literature, see now McAuley 2016.

19. For an exploration from a Kristevan perspective that focuses on Roman love elegy of the associations between and among time, gender, and genre, see now Gardner 2013: 145-80 on repetition and cyclicality (as opposed to the linear imperative of epic narrative) as characteristic of "women's time."

20. Hunter 1989: 21 and 32-38 offers a useful overview.

21. Numerous allusions to Medea occur en passant in the elegiac poetry of Ovid. In these glances at her story, she is typically depicted as a vindictive murderer of her own children; often, her name is omitted, a rhetorical strategy that confirms her literary celebrity: A.A. 1.336, nece 
natorum sanguinulenta parens (in a catalogue of crimes caused by feminine libido); A.A. 2.381-82, coniugis admissum uiolataque iura marita est / barbara per natos Phasias ulta suos (in a catalogue of betrayed women overpowered by wrath); Rem. 59-60, nec dolor armasset contra sua uiscera matrem,l quae socii damno sanguinis ulta uirum est (in a catalogue of women who have suffered for love); Am. 2.14.29, Colchida respersam puerorum sanguine culpant (in the context of Corinna's abortion). Cf. also A.A. 2.101-3 (the inefficacy of magic in love); A.A. 3.333 (Jason has betrayed Medea, Phasida iam matrem); Rem. 261-62 (love is more powerful than Medea's magic); Fasti 2.41-42 (Aegeus is deceived by Medea); Fasti 2.627 (a list of predecessors who have destroyed their families); Tr. 2.387-90 (a list of mythological love stories); Heroides 6 (Hypsipyle unknowingly foresees Medea's infanticide); Tr. 3.9 (Apsyrtus' murder provides the etymology for Tomi). Cf. also Schmitzer 2003. 22. For an overview of the elegiac cliché of seruitium amoris, see Fulkerson 2013.

23. See Spoth 1992: 198-205 on Heroides 12 as elegy; Bessone 1997: 11-41 offers a comprehensive overview of generic signposting in Heroides 12.

24. For further comparison of Catul. 76 and Her. 12, see Bessone 1995, and below, n. 38. Cf. also Binroth-Bank 1994: 54, Mastronarde 2002: 24-25, and Graf 1997: 28.

25. Cf. Pindar Py. 4.233: Medea is described as $\pi \alpha \mu \varphi \alpha ́ p \mu \alpha \kappa o \varsigma ~ \xi \varepsilon i ́ v \alpha$.

26. The irony of her powerlessness in the face of love has a parallel in Apollo's pursuit of Daphne in Metamorphoses 1. As the god of medicine, he has the ability to heal all wounds except those inflicted by Cupid (Met. 1.521-24). Apollo's divinity, however, as well as his masculinity, makes his amorous suffering an insignificant rationale for sorrow; rather, his love will truly conquer allincluding Daphne. Apollo is an incongruous elegiac lover, distancing himself entirely from the role when, with Daphne's transformation into a tree, he succeeds in asserting his permanent power over the girl's arboreal nature (1.557-67). At the close of the episode, Ovid signals the restoration of the epic code in the poem when he describes the healing god with the epithet Paean (1.566), a name synonymous with healing as early as the Homeric poems and gradually assimilated to Apollo himself: Graf 2009: 81-82. Prior to his infatuation with Daphne, Apollo had been busy maintaining order on earth; with the declaration that Daphne will live on in the form of the tree sacred to him, he simultaneously reaffirms the permanence of Augustan order, so abandoning a life of elegiac submission to the chaos of love and replacing it with a panegyric gesture. P. Knox 1986b: 14-18 provides a detailed discussion of Apollo as elegiac lover in this scene. See also Williams 2010 on the failure of Apollo in love, and Boyd 2016 and ead. 2017: 205-12 on the inefficacy of magic in the Circe episode of Rem. 249-90.

27. Again we see the inversion of the cliché of servitium amoris (above, n. 22).

28. See Gardner 2013: 8, 48-50.

29. James 2003: 173-83 discusses the problems posed in elegy by the prospect of pregnancy and childbirth; cf. Gardner 2013: 48 n. 52.

30. Bessone 1997 ad loc.; cf. Heinze 1997 ad loc. on the polyvalence of amor.

31. These verses present several textual problems; I follow here Bessone's text, based in part on that of Rosati 1990: 165-70. See Bessone 1997 ad loc. for detailed discussion. Heinze 1997 prints essentially the same text, except for the variant studioue in 12.149: see his discussion ad loc.

32. On the duplicity or doubleness of Medea's words in this section of the letter, see Bessone 1997 ad loc.

33. Jacobson 1974: 122 n. 32 observes that "these lines are rich in their pregnant implications." Cf. also Her. 6.127-28: Hypsipyle describes Medea as "more than a stepmother" (Medeam timui: plus est Medea nouerca; / Medeae faciunt ad scelus omne manus). On the points of contact and interplay between Heroides 6 and 12, see Rosati 1988; Fulkerson 2005: 40-55; and cf. Lindheim 2003: 114-33. On the imagery of "moreness" in Heroides 12, see below, nn. 44 and 45.

34. As one of my anonymous referees observes, the phrase dira nouerca also functions as an instance of "double-speak" in regard to Medea herself, who in the sequel to this episode is the "wicked stepmother" of Theseus. 
35. See Jacobson 1974: 114 and n. 13; Hinds 1993: 45 and n. 80; Bessone 1997 ad loc.; and cf. also Heinze 1997 ad loc., noting Heinsius' approval of this opening.

36. At Met. 7.21, Medea describes herself as regia uirgo; cf. Servius ad loc. for Virgil's use of regina (regis filia: abusiue dicit more poetico), and for a summary of views, Casali 1995: 5-6 and n. 6. Casali makes a convincing case that the word regina in Aeneid 6 alludes (at least primarily) to Ariadne.

37. And, as one of the anonymous referees reminds me, the "virtual genealogical paradigm" also has a basis in mythological fact, for Medea is the niece of Pasiphaë, the sister of her father Aeetes (cf. Apoll. Argon. 3.1074-76).

38. Cf. Miller 1993 and Bessone 1997: 287-88 on the metaliterary effect of memini, etc.; also Bessone 1995 for the relationship between Catul. c. 76 and Ovid's Medea, and for the suggestion (576 n. 6) that Medea's 'memini' replies to Catullus' opening words, 'si qua recordanti ...'.

39. Cf. Rosati 1988 on the imagery of childbirth used by Hypsipyle to allude to Medea at Her. 6.156-57.

40. Cf. Barchiesi 1993: 343: "Medea is passing from letter-writing to action-to scenic action."

41. Barchiesi 1993: 343; Heinze 1997 ad loc.; Bessone 1997 ad loc. provides ample bibliography. Cf. also Spoth 1992: 198-205 and Hinds 1993: 40-43.

42. Propertius in turn is "quoting" Virgil, who uses the term maius opus to distinguish the second half of the Aeneid from the first (Aen. 7.45)-immediately after his invocation of the Muse Erato, the same Muse invoked by Apollonius in beginning his Medea-book: see Hunter 1989 on Argon. 3.1-5.

43. Hardie 1993: 11-14.

44. On the importance of achieving "something greater" for tragic and epic heroes, see Barchiesi 1993; Williams 2012. Hinds 2011: 22-28 examines the role of "greatness" in the intertextual and metatextual relationship between Ovid's and Seneca's Medeas; see also Battistella 2015.

45. Cf. Spoth 1992: 203, Barchiesi 1993: 344-45; Heinze 1997 on Her. 12.212; and Bessone 1997: $28-41$, discussing the generic implications of literary-critical language concerning greatness. See also Hinds 1993: 41 for the suggestion of wordplay in the epithet ingentis and id. 2011: 22-25.

46. Newlands 1997: 178-92 sees the first section of the Medea episode in Metamorphoses 7 as a continuation of the character seen in Heroides 12 (viewed in a sympathetic light), but considers Medea's "metamorphosis" into a witch, beginning at 7.159, to constitute "a cardboard figure of evil" (180). While Newlands' observations regarding the metamorphosis of Medea are valuable, my discussion argues for a more complex understanding of Medea's character.

47. Hinds 1993; Barchiesi 1993; Binroth-Bank 1994 gives details on both similarities and differences passim.

48. Printed with upper-case first letters by Tarrant 2004, followed by Kenney 2011.

49. Cf. Kenney 2011 on Met. 7.11-73.

50. OLD s.v. 10b.

51. Cf. Boyd 2017: 36-37 on Ovid's use of the word pietas as shorthand for the Aeneid.

52. See Kenney 2011 ad loc. and id. 2001: 262: "the murder of her children[,] is alluded to almost casually in a way that represents her momentous sojourn in Corinth as hardly more than a brief stop-over in her devious aerial progress from Iolcus to Athens ..."; and cf. Binroth-Bank 1994: 144-45, "Von der Existenz der Kinder erfahren wir erst im Augenblick ihres Todes."

53. Bömer 1976 ad loc., Kenney 2011 ad loc.

54. Kenney 2011 ad loc.: "l'ordine delle parole suggerisce che male si riferisca anche a mater ... "una madre snaturata." Interestingly, Ovid uses another instance of male + perfect passive participle at Her. 6.157, in a passage referring to the doomed children of Medea: nec male parta diu teneat peiusque relinquat. On the wordplay in this line, see Rosati 1988.

55. On repetition as an essential characteristic of epic narrative, cf. Hardie 1993: 14-18, following Quint 1991; see also above, n. 8.

56. See Kenney 2011 ad loc., and on Met. 7.404-24. 
57. On the polyvalence of carmen in Ovid, see Sharrock 1994: 63-64; and cf. now Boyd 2016: 111-12, 118-20 and ead. 2017: 206-7. For attractive observations about the metaliterary character of Medea in Metamorphoses 7, see Williams 2012: 62-67.

58. See Williams 2012: 55.

59. Kenney 2011 on Met. 7.285: "in contrasto con i lunghi elaborati preliminari il ringiovanimento in sé avviene ed è descritto in un battibaleno."

60. See above, n. 16.

61. Bömer 1976 ad loc. and Kenney 2011 ad loc. note the probable allusion here by Ovid to the Rhizotomoi of Sophocles, as described by Macrobius Sat. 5.19.9.

62. On Medea's "paradoxical" powers in this scene, Williams 2012: 58-59.

63. See Keith 2000: 36-41 on the imagery used for Mother Earth in Latin epic; and see duBois 1988: 39-85 for Greek agricultural metaphors for intercourse and the female body. Kenney 2011 ad loc. details the Lucretian flavor of the description.

64. Cf. the references to Zeitlin 1996 and Hopman 2008 in nn. 2 and 3, above.

65. Identified as fragment 2a of the Epigrams in Goldberg and Manuwald 2018.

66. Much earlier versions of a portion of this essay were delivered as talks at the Università di Bologna and the Università di Roma, Tor Vergata; I thank my hosts and listeners at both institutions for lively questions and conversation. I also thank Francesca Mencacci and Anna Maria Thornton for their help with turning this into Italian and back again. Last but not least, I am grateful to the anonymous readers for Dictynna, whose interventions helped me to sharpen and refine my discussion.

\section{ABSTRACTS}

This essay examines Ovid's repeated use of the character and story of Medea, focusing on the phenomenon of repetition itself. Her appearances in Ovid's poetry are not only self-referential but also metatextual, allowing Ovid to explore and to comment upon the generic parameters of his work and upon the possibility of creating something radically new.

\section{INDEX}

Keywords: Medea, repetition, infanticide, gender, genre

\section{AUTHOR}

\section{BARBARA W. BOYD}

Bowdoin College

bboyd@bowdoin.edu 